\title{
Mould flux residues aid descaling of reheated austenitic stainless steel
}

\author{
J.-J. N. Mukadi ${ }^{1,2}$ and P. C. Pistorius*2,3
}

\begin{abstract}
The effects of mould flux residues on descaling of type 304 austenitic stainless steel were investigated, for simulated slab reheating conditions and hydraulic descaling. Several industrial and laboratory mould flux compositions and dosages were tested, and all of these were found to improve descaling substantially. This effect was associated with the elimination of the subscale containing nickel enriched metal tendrils and chromite (spinel). This subscale is characteristic of reheated austenitic stainless steel which does not have mould flux residues. In the presence of mould flux residues the subscale is absent, and nickel is oxidised and incorporated in a nickeliron-chromium spinel which is close to the steel/scale interface, but separated from the steel by a layer of chromium oxide and molten silicate.
\end{abstract}

Keywords: Stainless steel, Mould flux, Reheating, Hydraulic descaling, Oxide scale

\section{Introduction}

When, before hot rolling, slabs are reheated in an oxidising furnace atmosphere surface oxidation is inevitable. ${ }^{1}$ The resulting oxide scale is hydraulically removed with high pressure water sprays before hot rolling to ensure good surface quality of the hot rolled strip. For austenitic stainless steel, scale removal is hindered by the presence of a subscale which contains nickel enriched metal tendrils which anchor the scale to the steel. ${ }^{2}$

In the work reported here, the effect of mould flux residues on hydraulic descaling of reheated Type 304 austenitic stainless steel was investigated. Mould fluxes are synthetic slags which contain mainly $\mathrm{CaO}$ and $\mathrm{SiO}_{2}$ with alkali oxides $\left(\mathrm{Na}_{2} \mathrm{O}\right)$ and fluorides $\left(\mathrm{CaF}_{2}\right)$; the mould flux lubricates the contact surface between the continuous casting mould and the steel strand, influences the heat flux in the mould, and the unmelted and melted layers of flux on the steel surface reduce the loss of heat from the surface of the steel, protect the liquid steel from reoxidation and absorb inclusions from the steel. ${ }^{3}$

The mould flux solidifies against the copper mould, and a thin layer against the steel surface remains molten. ${ }^{4}$ Some of the mould flux exits the mould with the slab, and constitutes the mould flux consumption. While the mould flux consumption is variable (and depends on casting conditions and flux composition), ${ }^{4}$ the consumption typically corresponds to a layer $\sim 0.1 \mathrm{~mm}$ thick on the slab surface. Some of this remains on the slab surface after the slab exits the continuous caster; the mould flux residues are expected to affect subsequent scale growth and removal.

${ }^{1}$ Mintek, Private Bag X3105, Randburg 2125, South Africa

${ }^{2}$ Department of Materials Science and Metallurgical Engineering, University of Pretoria, Pretoria 0002, South Africa

${ }^{3}$ Department of Materials Science and Engineering, Carnegie Mellon University, Pittsburgh, PA 15213 3890, USA

*Corresponding author, email pistorius@ @mu.edu
The mould flux that remains on the slab surface is expected to be molten at the typical slab reheating temperature of $1250^{\circ} \mathrm{C} .^{3}$ The molten flux layer may be expected to affect oxidation of the steel in a similar manner to molten salts: ${ }^{5,6}$ internal oxidation was found to be more severe for austenitic stainless steel in contact with molten salts, causing the formation of a thicker subscale. The increased attack in molten salt appears to be caused by removal of protective oxides from the steel surface. However, the limited thickness of the molten mould flux layer would limit the extent to which the mould flux can remove protective oxides from the steel surface: the primary scale (which forms during reheating) is typically several millimetres thick, much thicker than the mould flux residue.

Apart from a possible effect on scale growth, the presence of a layer of molten flux would be expected to improve scale removal during hydraulic descaling, if cationic diffusion into the scale trapped the flux at the scale/steel interface. A molten layer at the scale/steel interface is expected to give easy descaling.

The effects of mould flux on scale morphology and removal were studied by reheating samples under conditions which were chosen to simulate industrial reheating, and subjecting the samples to subsequent hydraulic descaling, as described below.

\section{Experimental}

\section{Reheating and descaling}

The stainless steel used in this investigation was cut from the surface of continuously cast slabs and from hot rolled and pickled plate (15 mm thick). The composition of type 304 stainless steel used in experiments is $\mathrm{Fe}-$ $18 \cdot 16 \mathrm{Cr}-8 \cdot 09 \mathrm{Ni}-1 \cdot 305 \mathrm{Mn}-0 \cdot 40 \mathrm{Si}-0 \cdot 14 \mathrm{Mo}-0 \cdot 12 \mathrm{~V}-0 \cdot 09 \mathrm{Cu}-$ $0 \cdot 044 \mathrm{C}-0 \cdot 050 \mathrm{~N}-0 \cdot 03 \mathrm{Co}-0 \cdot 022 \mathrm{P}-0 \cdot 01 \mathrm{Ti}-0 \cdot 008 \mathrm{O}-0 \cdot 004 \mathrm{Al}-$ $0 \cdot 0033 \mathrm{~S}-0 \cdot 003 \mathrm{Nb}-0 \cdot 001 \mathrm{~B}$ (mass- $\%$ ). The steel samples were degreased (with alcohol) before reheating, and one 
Table 1 Compositions of commercial fluxes used in experiments, mass- $\%$

\begin{tabular}{lccc}
\hline & Type 832 & Type RF1 & Type 810 \\
\hline $\mathrm{SiO}_{2}$ & 35.92 & 33.97 & 34.10 \\
$\mathrm{CaO}$ & 32.53 & 38.98 & 35.34 \\
$\mathrm{Al}_{2} \mathrm{O}_{3}$ & 5.92 & 7.32 & 6.98 \\
$\mathrm{~F}$ & 3.16 & 3.32 & 5.35 \\
$\mathrm{Na}_{2} \mathrm{O}$ & 18.43 & 13.11 & 13.34 \\
$\mathrm{Fe}_{2} \mathrm{O}_{3}$ & 0.55 & 1.46 & 1.52 \\
$\mathrm{MgO}_{\mathrm{TiO}}$ & 2.6 & 0.96 & 1.43 \\
$\mathrm{TiO}_{2}$ & 0.19 & 0.14 & 0.30 \\
$\mathrm{MnO}$ & 0.057 & 0.035 & 2.81 \\
$\mathrm{~K}_{2} \mathrm{O}$ & 0.13 & 0.55 & 0.17 \\
\hline
\end{tabular}

surface of selected samples was covered with controlled amounts of mould flux. For slab samples, the surface covered with mould flux was the originally outer surface (wide face) of the slab.

Three commercial mould fluxes were tested, after decarburisation in air at $600^{\circ} \mathrm{C}$ for $15 \mathrm{~h}$. The compositions of the decarburised mould fluxes are given Table 1. Three simpler synthetic mould fluxes were also prepared from pure chemicals, to test the effects of fluoride and alkali oxides; the compositions of the synthetic fluxes are given in Table 2.

The steel samples were cut to size using a band saw and a water cooled abrasive disc cutter. Since stresses develop at the sample edges and corners during scale growth, samples had large lengths and widths in comparison to the scale thickness; the samples were typically $45 \times 45 \times 15 \mathrm{~mm}$ large. The sample corners were bevelled, to allow the samples to hang with their larger dimensions horizontal inside the vertical tube furnace (to avoid mould flux dripping from the upper sample surface, where the flux was placed). Grooves, $1.5 \mathrm{~mm}$ deep, on each side of the sample, served to secure the sample with Kanthal wire to a mullite rod. The furnace used for reheating and the gas mixing unit were as described before. ${ }^{2}$ The gas simulated the combustion product of methane, and consisted of $\mathrm{N}_{2}, \mathrm{CO}_{2}, \mathrm{H}_{2} \mathrm{O}$ $(15 \%)$ and $\mathrm{O}_{2}(3$ or $4 \%$ ), at a total flowrate of $5 \mathrm{Ndm}^{3} \mathrm{~min}^{-1}$; the inner diameter of the furnace tube was $76 \mathrm{~mm}$.

For the samples which were covered with mould flux, the surface dosage varied between 0.05 and $0.35 \mathrm{~kg} \mathrm{~m}^{-2}$; based on an assumed mould flux density of $2500 \mathrm{~kg} \mathrm{~m}^{-3}$ these correspond to mould flux film thicknesses of $20-140 \mu \mathrm{m}$. To apply the mould flux to the sample, the powdered flux was mixed into a slurry with alcohol and then deposited evenly on the sample.

Reheating temperatures were 1250,1280 and $1300^{\circ} \mathrm{C}$ (controlled using a furnace thermocouple, and verified with a handheld $\mathrm{R}$ type thermocouple), with reheating time of 2-6 h.

At the end of the scaling period, the sample was removed from the furnace manually. Care was taken to

Table 2 Compositions of fluxes prepared in laboratory, mass-\%

\begin{tabular}{llll}
\hline & SMF1 & SMF2 & SMF3 \\
\hline $\mathrm{SiO}_{2}$ & 40 & 40 & 50 \\
$\mathrm{CaO}$ & 40 & 40 & 50 \\
$\mathrm{CaF}_{2}$ & 20 & 0 & 0 \\
$\mathrm{Na}_{2} \mathrm{O}$ & 0 & 20 & 0 \\
\hline
\end{tabular}

remove the sample from the furnace in a rapid and reproducible way, to avoid cooling before descaling. The hot sample was subjected hydraulic descaling with a high pressure water spray. For descaling, the sample was placed on a chain driven cart which moved the sample at a speed of $0.8 \mathrm{~m} \mathrm{~s}^{-1}$ underneath the water spray. Tap water was used for descaling, delivered with a high pressure pump through a commercial nozzle (Lechler 694.726) with an elliptical orifice and $26^{\circ}$ spray angle. The nozzle was angled towards the approaching sample by $15^{\circ}$ from the vertical. The descaling water flowrate was varied between 54 and $66 \mathrm{dm}^{3} \min ^{-1}$, and the distance between the nozzle and the sample was $96 \mathrm{~mm}$; the resulting water impact pressure on the sample was 1.4-2 MPa. These conditions are similar to industrial descaling. More detail of the descaling system, including calibration of flow measurements, is given elsewhere. ${ }^{7}$

\section{Analytical techniques}

After visual observation, reheated and descaled samples and removed scale were mounted in epoxy resin, and cross-sections polished with diamond paste for examination by SEM. Backscattered electron imaging was used, with EDX of various phases in the scale.

X-ray diffraction (XRD, using Co $K_{\alpha}$ radiation) was used to identify phases. X-ray photoelectron spectroscopy was used to test for the presence of hexavalent chromium in the scale.

\section{Results and discussion}

\section{Scale structure}

In line with previous results, ${ }^{1,2,8}$ the weakly adherent outer scale consisted mainly of iron oxide. X-ray diffraction showed the main phases to be magnetite and hematite. Compositions of the outer scales are given in Table 3. Cross-sections of outer scale are shown in Fig. 1. These were similar for samples with and without mould flux coatings, except that the scale contained slightly more $\mathrm{CaO}$ and $\mathrm{Na}_{2} \mathrm{O}$ for samples where were coated with mould flux before reheating.

While the outer scales were similar in phases and composition, the inner scales were quite different: as observed previously, ${ }^{2}$ austenite (Ni enriched metal tendrils) intergrown with chromite was found in the inner scale of the samples without mould flux (Fig. 2),

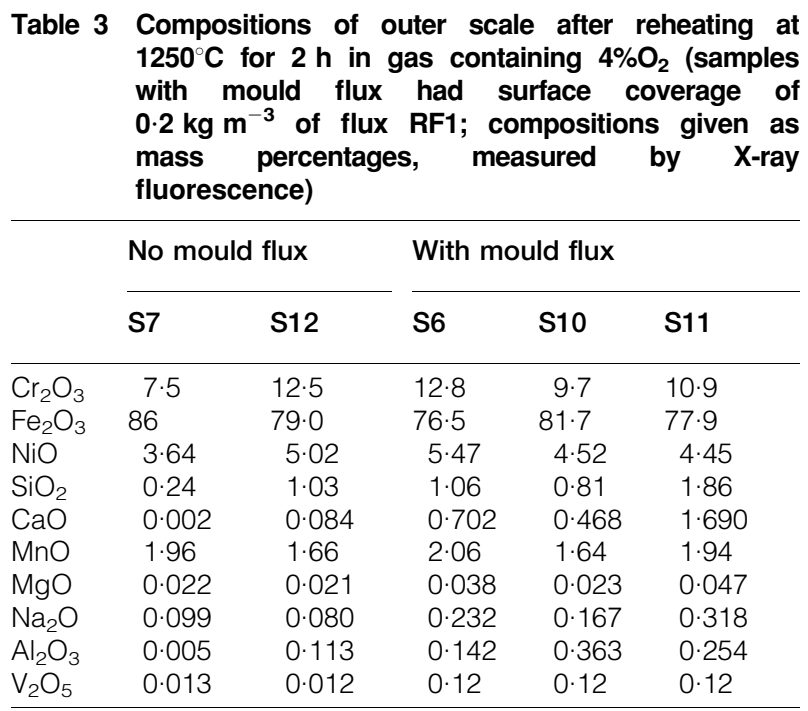




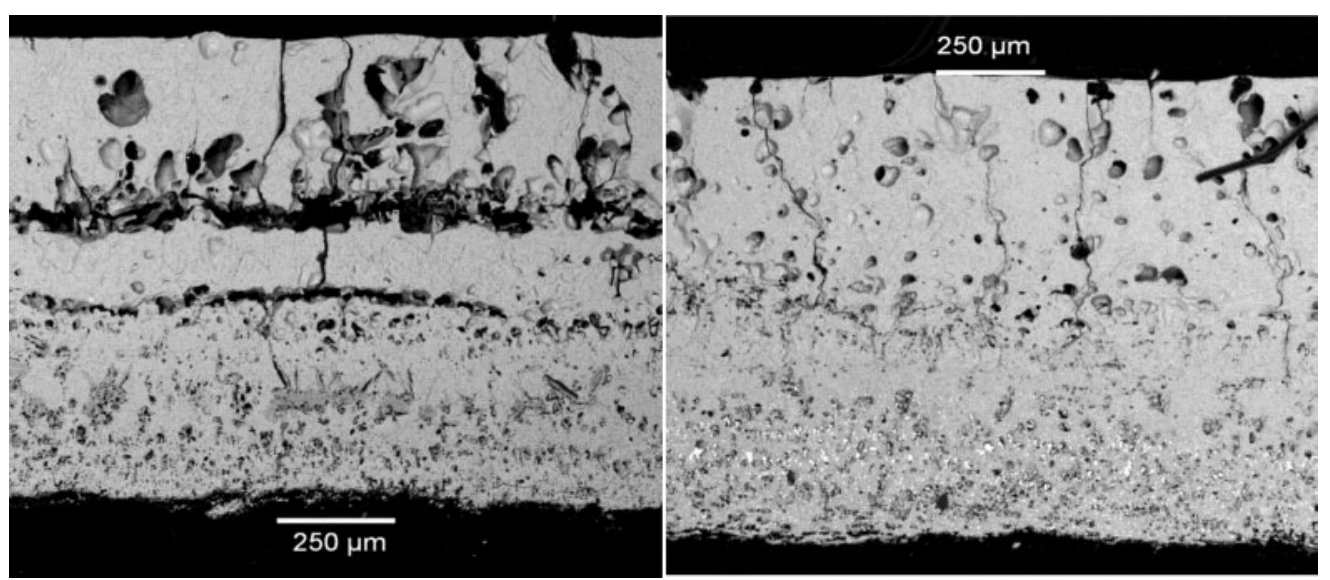

1 Cross-sections through scale removed from sample covered with mould flux (RF1, $0.11 \mathrm{~kg} \mathrm{~m}^{-2}$ ) (left) and without mould flux (right) after reheating $\left(1280^{\circ} \mathrm{C}, 4 \% \mathrm{O}_{2}, 6 \mathrm{~h}\right)$ and hydraulic descaling: outer surface is towards top of images; interface with inner scale towards bottom; bright spots in image at right are metal remnants; backscattered electron images

but metal tendrils were absent from the samples covered with mould flux. In addition, the phases present in the scale closest to the metal surface were different: XRD showed spinel (chromite) together with austenite (metal) for the samples without mould flux, whereas the inner scale on samples with mould flux contained spinel and also eskolaite $\left(\mathrm{Cr}_{2} \mathrm{O}_{3}\right)$. The higher magnification backscattered electron micrograph of Fig. 3 shows these phases on the sample with mould flux, and also shows the presence of a silicate phase, which derived from the mould flux itself (this is apparently glassy after cooling to room temperature, and hence was not detected by XRD).

In addition to the difference in the phases which are present on the sample with mould flux, the composition of the spinel phase in the inner scale was quite different from chromite $\left(\mathrm{FeCr}_{2} \mathrm{O}_{4}\right)$, which is the spinel which is normally encountered in the subscale on reheated austenitic stainless steel. This difference is shown by the microanalysis results which are summarised in Table 4. The major difference is that the spinel phase contains nickel, for the samples which were coated with mould flux before reheating. That is, for samples which were coated with mould flux the nickel is not concentrated in the metal tendrils, but rather reports to a spinel oxide phase.

If it is assumed that the spinel follows $\mathrm{M}_{3} \mathrm{O}_{4}$ stoichiometry, and that the nickel is divalent and the chromium trivalent, the average composition of the spinel phase in the inner scale of samples with mould flux is approximately $\left(\mathrm{Ni}_{0.47} \mathrm{Fe}_{0.53}\right)\left(\mathrm{Fe}_{0.66} \mathrm{Cr}_{1.34}\right) \mathrm{O}_{4}$. In this formula, the nickel and divalent iron are given first, and the trivalent iron and chromium second. For the samples without mould flux the spinel in the subscale is approximately $(\mathrm{Fe})\left(\mathrm{Fe}_{0 \cdot 21} \mathrm{Cr}_{1 \cdot 79}\right) \mathrm{O}_{4}$. The higher content of trivalent iron and the presence of nickel in the spinel (for samples with mould flux) both indicate that this spinel formed under more oxidising conditions than in the absence of mould flux. This agrees with the model calculations reported by Kjellqvist et al. for the somewhat lower temperature of $1000^{\circ} \mathrm{C} ;{ }^{9}$ Kjellquist et al. predicted that Ni containing spinel can be formed by the oxidation of Type 304 stainless steel, but only for oxygen activities which are sufficiently high to give full oxidation of the metal. In line with this, the oxygen activity in equilibrium with the two spinel compositions
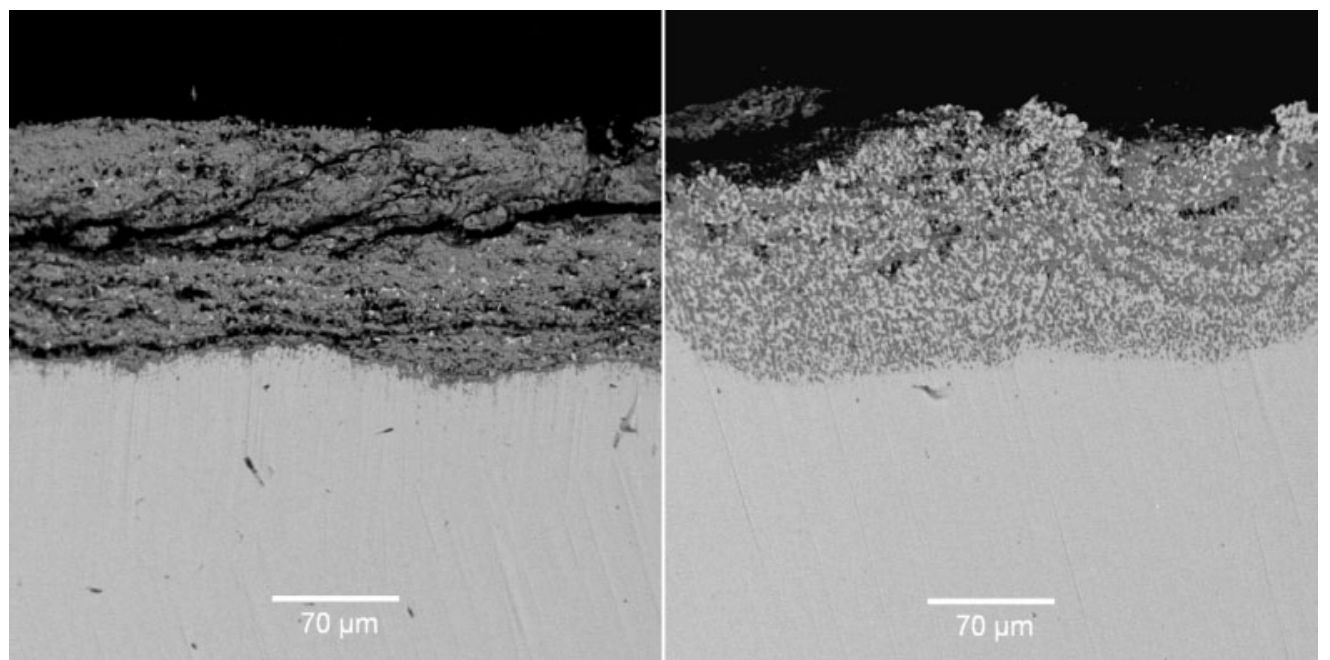

2 Difference in scale morphology for sample covered with mould flux (RF1, $0.17 \mathrm{~kg} \mathrm{~m}^{-2}$ ) (left) and without mould flux (right) after reheating $\left(1250^{\circ} \mathrm{C}, 4 \% \mathrm{O}_{2}, 4 \mathrm{~h}\right)$ : backscattered electron images; scale is in upper part of images; steel in lower part 


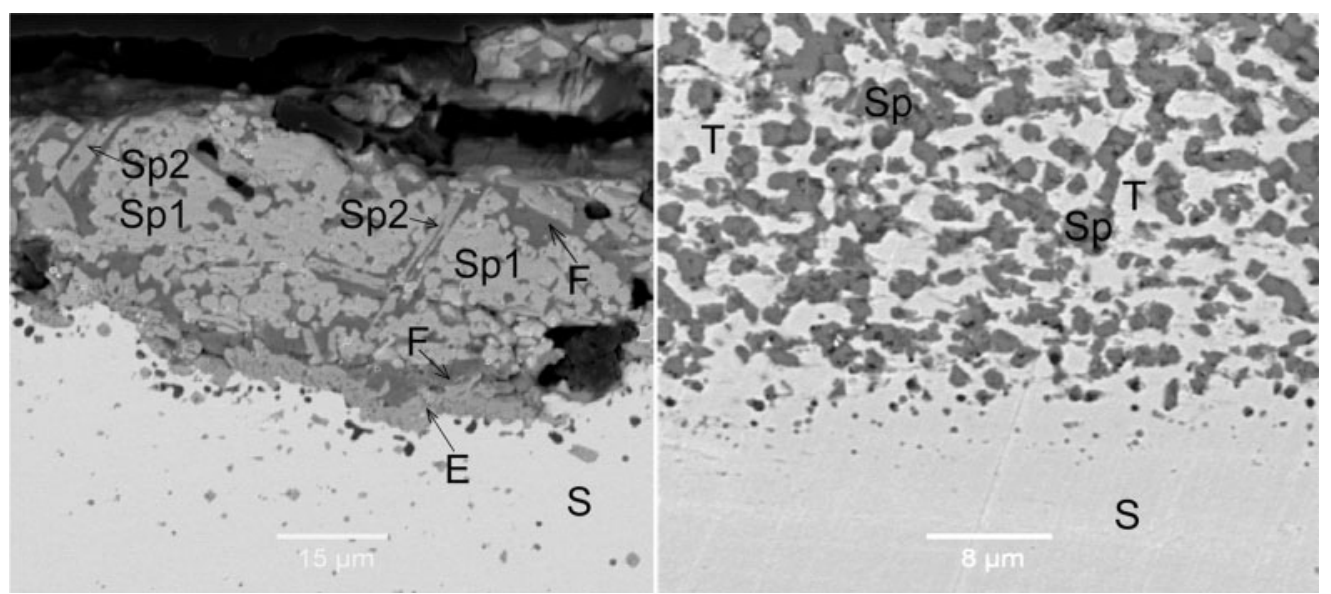

3 Higher magnification view of difference in scale morphology for sample covered with mould flux (type 832, $0.15 \mathrm{~kg} \mathrm{~m}^{-2}$ ) (left) and without mould flux (right) after reheating $\left(1280^{\circ} \mathrm{C}, 4 \% \mathrm{O}_{2}, 6 \mathrm{~h}\right)$ : backscattered electron images; ' $S$ ' is steel, ' $E$ ' eskolaite, 'Sp', 'Sp1' and 'Sp2' are spinel phases; ' $F$ ' is silicate based on mould flux; and ' $T$ ' is metal tendrils; see Table 4 for microanalyses

given above were estimated with FactSage ${ }^{10}$ (using the 'ASpinel' solid solution model for spinel) to be $10^{-8}$ atm (sample with mould flux) and $10^{-15}$ atm (sample without mould flux) respectively, for a temperature of $1250^{\circ} \mathrm{C}$.

The absence of nickel enriched tendrils for samples with mould flux deposits is hence related to establishment of more oxidising conditions, which allowed the nickel to be incorporated in a spinel product phase. However, it is not clear how the mould flux residues lead to this. Part of the role of the mould flux residues appears to be to allow the dissolution of the transition metals: as Table 4 shows, the silicate melt (derived from the mould flux) close to the metal/scale interface contained significant levels of chromium, nickel and iron. The silicate melt hence apparently acted as a medium to transport chromium, nickel and iron from the steel surface, while simultaneously separating the spinel from the metal surface (so allowing a higher effective oxygen activity in the spinel). The effect does not depend on the details of the mould flux composition: the effect was found for industrial and synthetic mould fluxes, with and without $\mathrm{CaF}_{2}$ and $\mathrm{Na}_{2} \mathrm{O}$.

Part of the effect of mould flux residues hence appears to be that $\mathrm{NiO}$ can dissolve in the mould flux, and that this favours nickel oxidation. There are limited data on nickel oxide dissolution in silicate slags, but Lee et al. have summarised available data on the nickel oxide capacity of $\mathrm{CaO}-\mathrm{SiO}_{2}-\mathrm{FeO}$ slags. ${ }^{11}$ They propose that $\mathrm{NiO}$ dissolves in the slag through the oxidation reaction

$$
\mathrm{Ni}+0 \cdot 5 \mathrm{O}_{2}+\mathrm{O}^{2-}=\mathrm{NiO}_{2}^{2-}
$$

In this reaction, $\mathrm{O}^{2-}$ anions provided by the slag (mould flux) react with the nickel oxidation products to form nickel oxide anions $\left(\mathrm{NiO}_{2}^{2-}\right)$ which dissolve in the mould flux; the presence of iron oxide in the flux (which was found by microanalysis, Table 4) also enhances dissolution of nickel oxide. ${ }^{11}$

According to this mechanism, the beneficial effect of the mould flux would depend on its basicity (although the effect is not particularly strong: the nickel oxide capacity of $\mathrm{C}_{2} \mathrm{~S}$ saturated slag is only three times that of lower basicity slag with $X_{\mathrm{CaO}} / X_{\mathrm{SiO}_{2}}=0.5$ to $\left.0 \cdot 7\right){ }^{11}$

\section{Chromium oxidation state}

X-ray photo electron spectroscopy was performed on the scale from samples which had been reheated with and without mould flux deposits. The aim was to test whether basic mould flux components $\left(\mathrm{CaO}\right.$ and $\left.\mathrm{Na}_{2} \mathrm{O}\right)$ had led to the formation of hexavalent chromium during scale growth. Industrial preparation of hexavalent chromium salts involves oxidation in the presence of basic oxides, ${ }^{12}$ and if this were to occur it may contribute to the change in scale structure. Hexavalent chromium would have given a peak at an average binding energy of $579 \cdot 7 \pm 1 \cdot 2 \mathrm{eV},{ }^{13}$ but no such peak was found after

Table 4 Compositions of phases in the inner scale, as determined by EDX (cations only, average mass percentages with $95 \%$ confidence intervals) (reheating conditions: $1280^{\circ} \mathrm{C}, 4 \% \mathrm{O}_{2}, 6 \mathrm{~h}$; phases labelled as in Fig. 4; ' $\mathrm{NF}$ ' indicates absence of mould flux; '832', 'SMF2' and 'SMF3' refer to mould fluxes (compositions in Tables 1 and 2)

\begin{tabular}{|c|c|c|c|c|c|c|c|c|c|c|c|c|}
\hline \multirow{2}{*}{$\begin{array}{l}\text { Phase } \\
\text { Flux }\end{array}$} & \multirow{2}{*}{$\frac{\mathrm{T}}{\mathrm{NF}}$} & \multirow{2}{*}{$\frac{S p}{N F}$} & \multicolumn{3}{|c|}{ Sp1 (spinel) } & \multirow{2}{*}{$\frac{\mathrm{Sp} 2}{832}$} & \multicolumn{3}{|c|}{ E (eskolaite) } & \multicolumn{3}{|c|}{ F (silicate) } \\
\hline & & & 832 & SMF2 & SMF3 & & 832 & SMF2 & SMF3 & 832 & SMF2 & SMF3 \\
\hline $\mathrm{Cr}$ & $4 \cdot 7 \pm 2 \cdot 4$ & \pm 5 & +0.6 & $50 \pm 2$ & $6 \pm 1.5$ & 72 & $90 \pm 4$ & $87 \pm 5$ & $90 \pm 4$ & $10 \pm 8$ & $9 \pm 6$ & $14 \pm 8$ \\
\hline $\mathrm{Ni}$ & $14 \cdot 4 \pm 2 \cdot 2$ & $1 \cdot 4 \pm 1 \cdot 4$ & $16 \cdot 1 \pm 0.5$ & $18 \cdot 2 \pm 1 \cdot 2$ & $11 \cdot 4 \pm 1 \cdot 7$ & $0.8 \pm 0.5$ & $0.1 \pm 0.2$ & $0.9 \pm 0.8$ & $0.5 \pm 1$ & $1 \cdot 7 \pm 0 \cdot 3$ & $1 \cdot \overline{5} \pm 2$ & $4 \pm 2$ \\
\hline $\mathrm{Fe}$ & $80 \pm \overline{2} \cdot 7$ & $38 \pm 6$ & $38.4 \pm 0.5$ & $28 \cdot 4 \pm 1 \cdot 4$ & $29 \cdot 8 \pm 2 \cdot 3$ & $25 \pm 5$ & $8 \pm \overline{5}$ & $9 \pm \overline{2}$ & $5 \pm \overline{3}$ & $6.5 \pm 2.5$ & $18 \pm 2$ & $1 \overline{5} \cdot 7 \pm 1 \cdot 4$ \\
\hline $\mathrm{Si}$ & $\ldots$ & $1 \cdot 4 \pm 1 \cdot 3$ & $0.3 \pm 0.3$ & $0.5 \pm 0.2$ & $0.5 \pm 0.4$ & $\ldots$ & $0 \cdot \overline{3} \pm 0 \cdot 1$ & $0 \cdot \overline{8} \pm 0.8$ & $1 \cdot \overline{0} \pm 1 \cdot 6$ & $31 \pm 3$ & $43 \pm 6$ & $30 \pm \overline{5}$ \\
\hline $\mathrm{Ca}$ & $\ldots$ & $\ldots$ & $0.6 \pm 0.2$ & $0.6 \pm 0.2$ & $1 \cdot 4 \pm 0.2$ & $\ldots$ & $0.5 \pm 0.1$ & $0.9 \pm 0.6$ & $1.6 \pm 0.8$ & $50 \pm 8$ & $21 \pm 2$ & $36 \pm 4$ \\
\hline $\mathrm{Na}$ & $\ldots$ & $\ldots$ & $1.5 \pm 0.3$ & $0.3 \pm 0.5$ & $0 \cdot 7 \pm 1 \cdot 1$ & $\ldots$ & & $0.2 \pm 0.2$ & $0.2 \pm 0.3$ & $30.1 \pm 0.1$ & $5 \cdot 4 \pm 0.7$ & $0.1 \pm 0.2$ \\
\hline $\mathrm{Mn}$ & $\ldots$ & $6 \pm 3$ & $4.4 \pm 0.5$ & $2.5 \pm 0.9$ & $1 \cdot 4 \pm 1 \cdot 0$ & $0.4 \pm 0.3$ & $0.6 \pm 0.2$ & $0.3 \pm 0.3$ & $1 \cdot 0 \pm 1 \cdot 3$ & $30.8 \pm 0.2$ & $0.6 \pm 0.7$ & $0.8 \pm 0.9$ \\
\hline
\end{tabular}




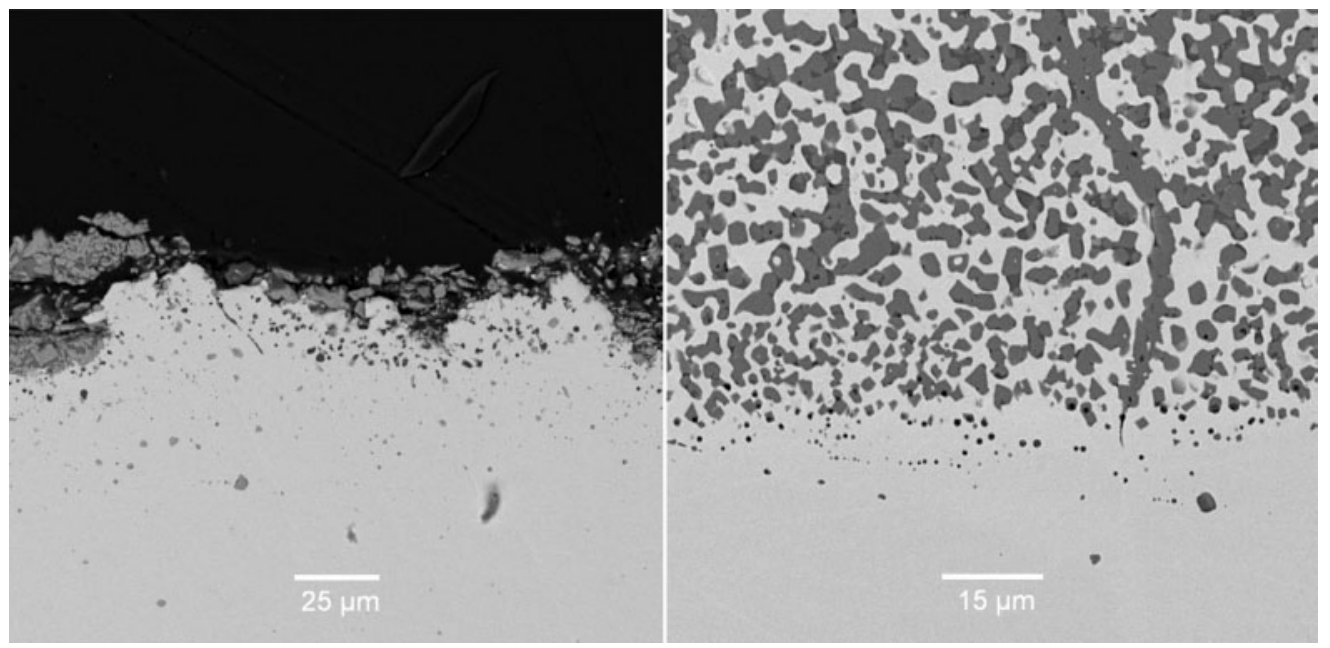

4 Cross-sections through residual scale on reheated plate samples with mould flux deposit (type $832,0 \cdot 15 \mathrm{~kg} \mathrm{~m}^{-2}$ ) (left) and without mould flux (right) after reheating $\left(1280^{\circ} \mathrm{C}, 3 \% \mathrm{O}_{2}, 6 \mathrm{~h}\right)$ and descaling (impact pressure $2 \cdot 2 \mathrm{MPa}$, total water applied to sample $31.7 \mathrm{dm}^{3} \mathrm{~m}^{-2}$ ): backscattered electron images

deconvolution analysis. This means that oxidation of chromium to the hexavalent state did not occur to a significant extent and hence was not the origin of the differences in scale structure.

\section{Scale thickness}

Despite the effect of mould flux residues to promote oxidation of nickel, the overall extent of oxidation was slightly smaller for samples with mould flux deposits. Typical scale thicknesses after reheating in $3 \% \mathrm{O}_{2}$ for $6 \mathrm{~h}$ at $1280^{\circ} \mathrm{C}$, followed by hydraulic descaling were as follows. For the samples without mould flux the removed scale was $875 \mu \mathrm{m}$ thick, and the residual scale thickness was $580 \mu \mathrm{m}$, giving a total scale thickness after reheating of $1.455 \mathrm{~mm}$. For samples with mould flux deposits the removed scale was $1100 \mu \mathrm{m}$ thick, and the residual scale thickness was $30 \mu \mathrm{m}$ (in only a few places on the metal substrate; many places had essentially no residual scale), so up to $1.130 \mathrm{~mm}$ of scale had formed during reheating. Hence, the effect of mould flux residues was to decrease oxidation slightly. Measurement of the decrease in metal thickness after reheating confirmed that the presence of mould flux caused a slight decrease in the scale growth rate. This difference in behaviour between slabs with and without mould flux was also observed for short reheating time. For samples with mould flux reheated for $2 \mathrm{~h}$ with $3 \%$ free oxygen at $1250^{\circ} \mathrm{C}$, some parts of the steel surface were found to be quite unoxidised, indicating a protective effect of the mould flux.

\section{Descaling}

The large difference in scale structure for samples with mould flux residues (compared with samples without mould flux) was also reflected in the descaling behaviour. Visual observation of the samples without mould flux after hydraulic descaling showed the presence of residual scale (subscale, $\sim 500 \mu \mathrm{m}$ thick) and a roughened surface. In contrast, the samples with mould flux deposits had only a few places with residual scale, but the surfaces were mostly fully descaled. This difference is illustrated by the cross-sections of descaled samples shown in Fig. 4. The outer surfaces of the samples are compared in Fig. 5, which confirms the large differences in appearance. In Fig. 5, some areas of the sample with mould flux had no residual scale (brightest areas), much of the surface was covered with $\mathrm{Cr}_{2} \mathrm{O}_{3}$ (light grey), and needle-like spinel was visible on the rest of the surface;

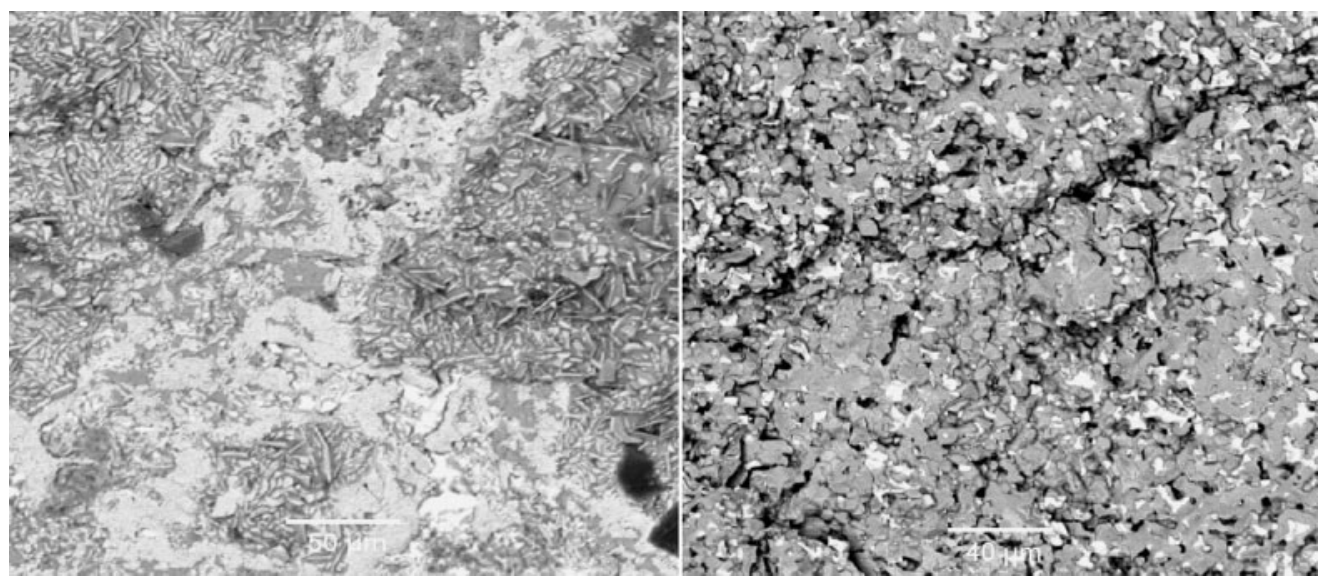

5 Difference in exterior appearance of samples after reheating $\left(6 \mathrm{~h}, 4 \% \mathrm{O}_{2}, 1280 \mathrm{C}\right)$ and hydraulic descaling (impact pressure $1.5 \mathrm{MPa}$; total water applied to sample $26 \mathrm{dm}^{3} \mathrm{~m}^{-2}$ ): sample with mould flux at left (flux type $810,0.11 \mathrm{~kg} \mathrm{~m}^{-2}$ ); sample without flux at right; backscattered electron images 
the sample without mould flux was covered with chromite (dark grey areas) and nickel enriched metal tendrils (bright areas).

A series of trials was performed to test the effects of reheating conditions and mould flux dosage on descaling. ${ }^{7}$ For samples with mould flux, changes in reheating temperature $\left(1250-1300^{\circ} \mathrm{C}\right)$, time $(2-6 \mathrm{~h})$ and the free oxygen $(3-4 \%)$ were found to have little effect on descaling effectiveness, because descaling was always effective, with little residual scale. In these experiments, the mould flux dosage varied between 0.05 and $0 \cdot 35 \mathrm{~kg} \mathrm{~m}^{-2}$, corresponding to average molten flux thicknesses of 19 to $135 \mu \mathrm{m}$ on the steel surface. All the mould flux surface concentrations were found to give better descaling results, but the best results were found for mould flux surface concentration $\sim 0.16 \mathrm{~kg} \mathrm{~m}^{-2}$ (60 $\mu \mathrm{m}$ film thickness). Beyond $0 \cdot 3 \mathrm{~kg} \mathrm{~m}^{-2}(115 \mu \mathrm{m})$ the slab surface was found to contain some black spots after descaling, possibly an excess of the unreacted mould flux on the steel surface. Below $0.08 \mathrm{~kg} \mathrm{~m}^{-2}(30 \mu \mathrm{m})$ of mould flux dosage it was difficult to obtain an even distribution of flux over the sample surface, but even so descaling was effective. While all mould fluxes were found to give better descaling and steel surface quality, type 832 was found to be the best according to the descaled slab surface quality, followed by type RF1. Of the three synthetic mould fluxes used, it was found that mould flux SMF1 $\left(20 \mathrm{CaF}_{2}-40 \mathrm{CaO}-40 \mathrm{SiO}_{2}\right)$ gave the best descaling and better slab surface quality, similar to that obtained with mould flux type 832. (Descaled surface quality was assessed by visual examination of the samples, and SEM observation of both the metal/ residual scale interface (cross-sectioned samples) and the exterior surface of the descaled samples.)

For samples without mould flux, a substantial subscale remained attached to the samples after descaling, and increases in temperature and longer reheating times were found to increase the extent of oxidation slightly, with poorer surface quality after descaling; the free oxygen content ( 3 and $4 \%$ ) of the gas during reheating was found not to have major impact on the extent of oxidation or descaling.

\section{Conclusions}

Mould flux residues strongly change the nature of the inner scale (due to enhanced oxidation of nickel). The change in the nature of the scale/steel interface was found to enhance the descaling of the contaminated slabs, associated with the absence of nickel enriched tendrils. For all samples which were coated with mould flux before reheating, a visual assessment indicated descaling to be complete or nearly so.

For samples without mould flux residues, a substantial residual scale $(\sim 500 \mu \mathrm{m}$ thick) remained on the samples after descaling in all cases.

The detail of the mechanism of the effect of the mould flux on oxidation remains unclear; compared with samples without mould flux the observed effect of mould flux combines more strongly oxidising conditions (causing the nickel to be oxidised and incorporated in a nickel-iron-chromium spinel) with a slightly lower rate of oxidation, and separation of the spinel from the metal by layers of $\mathrm{Cr}_{2} \mathrm{O}_{3}$ and of silicate melt.

\section{Acknowledgements}

This research was carried out with financial and material support from Columbus Stainless and the University of Pretoria. Financial support by the Technology and Human Resources for Industry Programme managed by the National Research Foundation and financed by the dti (South Africa) is acknowledged gratefully.

\section{References}

1. N. Birks and G. H. Meier: 'Introduction to oxidation of metals', 110-113, 160-162; 1983, London, Edward Arnold.

2. P. C. Pistorius, N. A. Quagraine and C. Coetzee: J. S. Afr. Inst. Min. Metall., 2003, 103, 607-615.

3. K. C. Mills, A. B. Fox, Z. Li and R. P. Thackray: Ironmaking Steelmaking, 2005, 32, 26-34.

4. R. Saraswat, A. B. Fox, K. C. Mills, P. D. Lee and B. Deo: Scand. J. Metall., 2004, 33, 85-91.

5. A. U. Seybolt: Oxid. Met., 1970, 2, 161-171.

6. C.-J. Wang and T.-T. He: Oxid. Met., 2002, 58, 415-437.

7. J.-J. N. Mukadi: 'Effect of mould flux on scale adhesion to reheated stainless steel slabs', MSc thesis, University of Pretoria, Pretoria, South Africa, 2008.

8. Y. Riquier and C. Dumortier: Mater. Technol., 1997, 85, 15-22.

9. L. Kjellqvist, M. Selleby and B. Sundman: Calphad, 2008, 32, 577592.

10. C. W. Bale, P. Chartrand, S. A. Degterov, G. Eriksson, K. Hack, R. Ben Mahfoud, J. Melançon, A. D. Pelton and S. Petersen: Calphad, 2002, 26, 189-228.

11. S. H. Lee, S. M. Moon, J. H. Park and D. J. Min: Metall. Mater. Trans. B, 2002, 33B, 55-59.

12. B. J. Page and G. W. Loar: in 'Kirk-Othmer Encyclopedia of chemical technology', Vol. 6, 526-571; 2004, New York, John Wiley \& Sons.

13. US Secretary of Commerce: 'NIST X-ray photoelectron spectroscopy database', Version 2.0; 1989, Washington, DC, US Secretary of Commerce. 